广二裁分るなに委立っ次第法にも收刑年

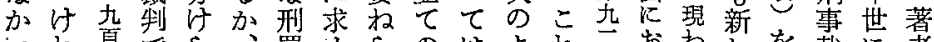

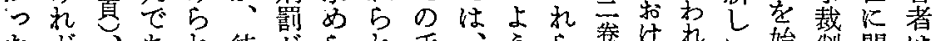

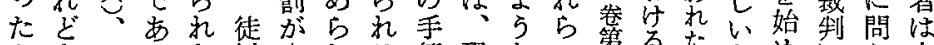

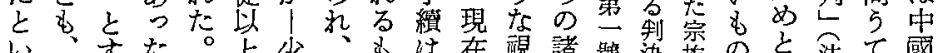

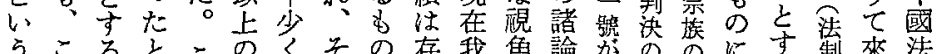

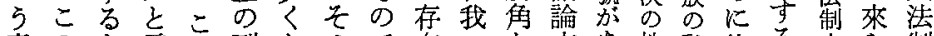
意の多言の刑之ので在々を交古性私位る史ら制 味このつ意怔案あ非の二方格型置、學机史

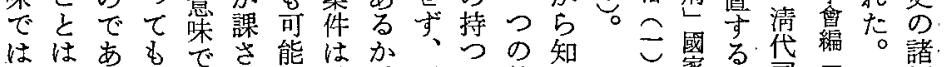

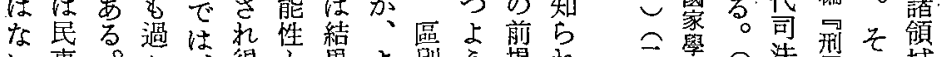

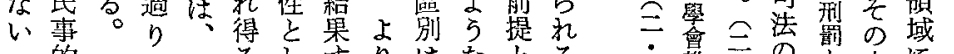

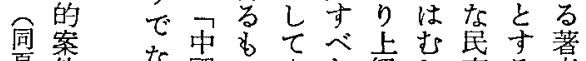

頁委な國の门級し事る著

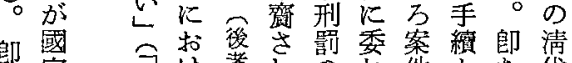

苦家

前廷

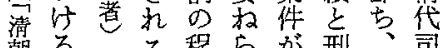
朝るでる程らが刑、司 完雜諭の炎中に。

完誈芳諸國でお

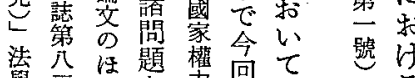

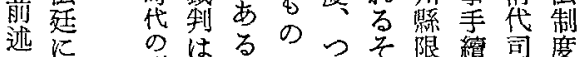

の持型吉加前まれりと法の

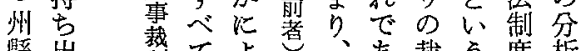

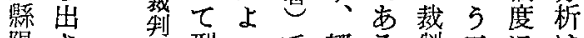

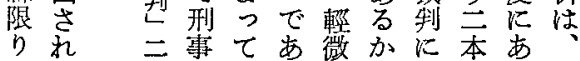

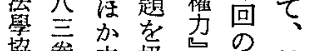

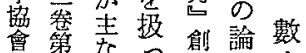

雜第なっ嬖交々

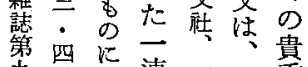

九號連二董

卷清請公清朝業

第清朝交年時績

㗔司制中最所の多

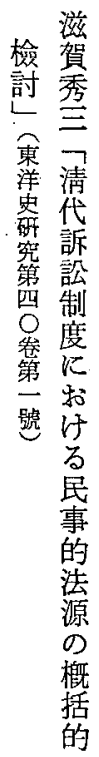

本らつ狀な文事寶典い聽の思とけ對はまるその

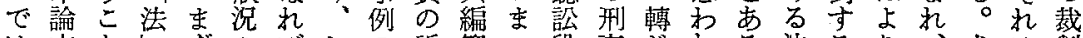

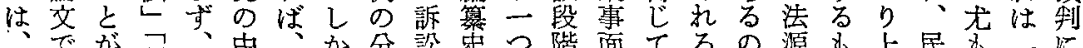

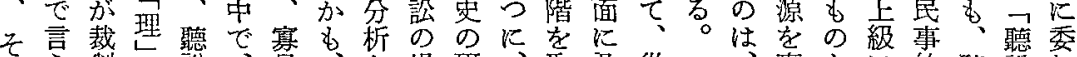

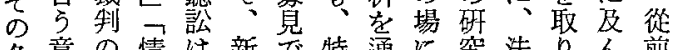
各意の情は新で特通飞究法り久前 名味要調たはにじ打成源上たの

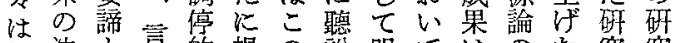
何法々言的提の訟明てはの卧究究 加源さ換色供論段 5 少分成は彇

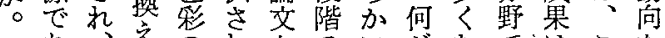

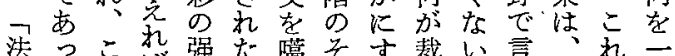

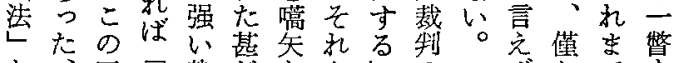

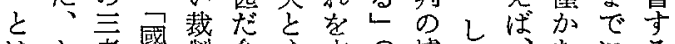

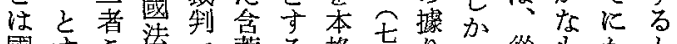

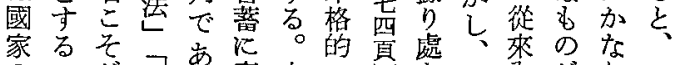

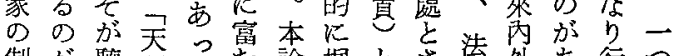

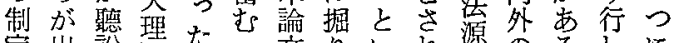

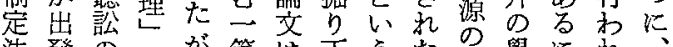

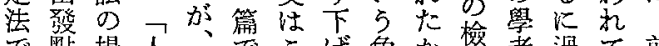
で點場人、でこげ角か检者過て前

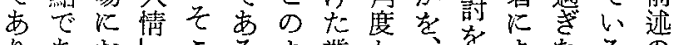

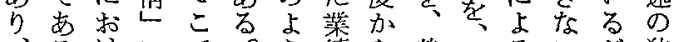

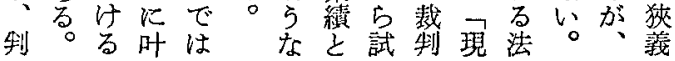

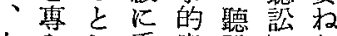
大 5 乙委案訟出 略考七极件化的 以察聽らのはかた 上の訟れ爭刑口案 の對をる訟事自件 占象置手た的理の

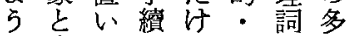

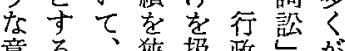
意る。狹扱政し肪 味合本議 5 的立正 いあ文刑の要さ民 でるで事で露れ事 言。手はのる性 わ表こ絀な案手の 颀題のと件繢强 $\tau 反$ 聽呼っむ領W いᄀ訟びたも域案 る民段、がとに件 も事階こ、含で の的治れ著り安あ

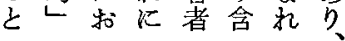




\section{書 弪}

情情味や味すがめる5生をの以女例詇に裁いて件語

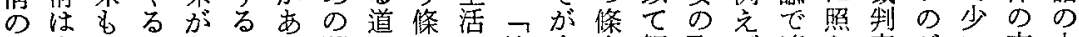

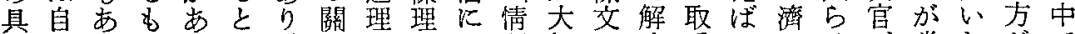
體然るのりい、鍵をと挂切飞決戻三きせが常しがで 性的。で、ら制で言概计七で一寸權重守ば法で、多愿

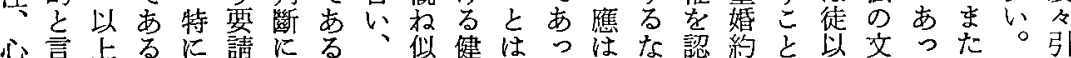

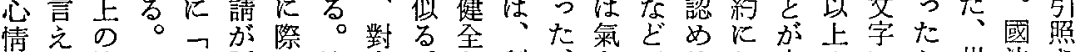

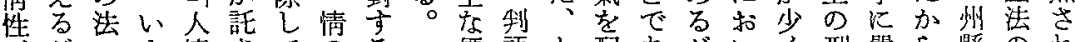
がが・ま情さてのる價語と配古がいく刑嚴ら縣のれ

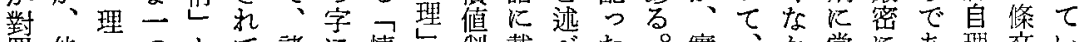

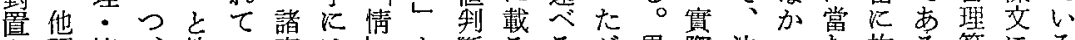

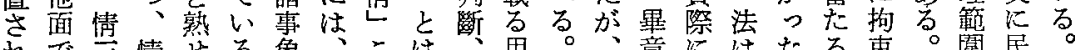

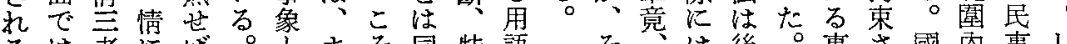

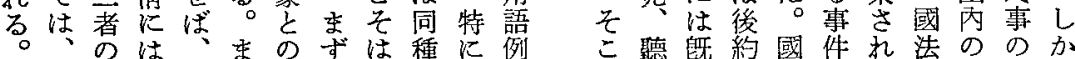
こ法間友そた關具: の本に の・で好れ、連體中事衡徵 上理は的は情飞的國物感才 万市な本火打事的飞覺る

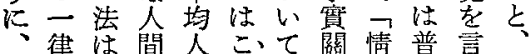
理性實閣がこ、同㐿理遍

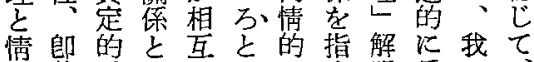

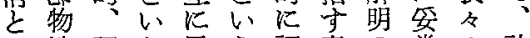
は性理ち思 5評意の當の社 對に・意い意價味た言言會

で訟成者法でるが輕法し はの等々娄と引罪源 む場實の民照はと國 して索成事輕 万認婚的心到まり 、め後側懲のるつ得は 準裁てで面らでとてる言 情制金安しは心擬当及 酷官錢前見めなら律のし 理は賠約てといこをはな

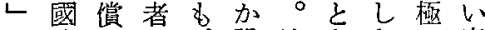
こ法をに、說法多なめ案

な著のるけのべ供本直ら析起事中れ理のたたれ立 い者理べれ實た、貿接こさ厝因的にる結に働こるがし か心念きど現折解ににれれ大す法數。論よをとお最な

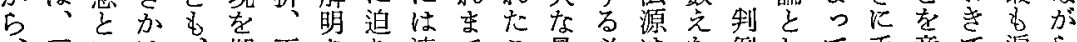
、素いは、期下さり清でこ量必壮な例して手意て遍ら

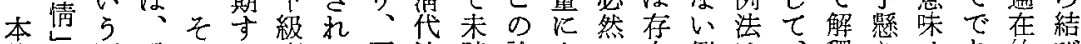
論二圖暗のる廳て更法踏論上の在例任、釋りせあ的び

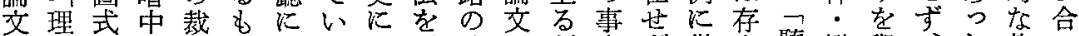
の死摸制の扣名は對分に制實式從在聽變與、た裁っ

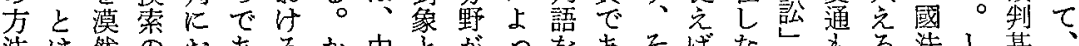

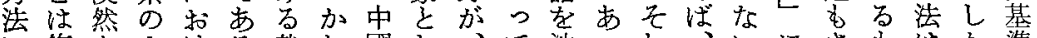

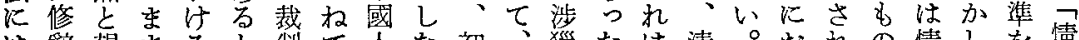

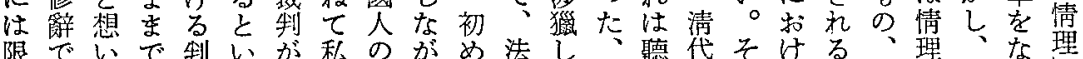

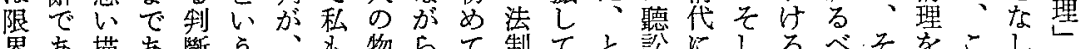

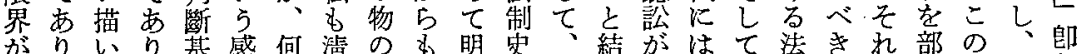

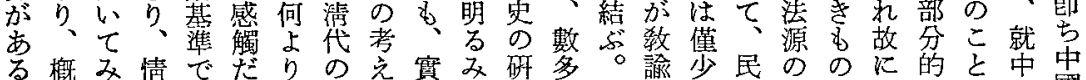

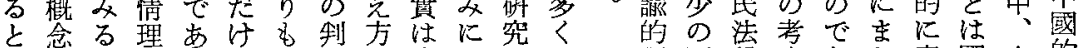
烧䙺だ少は具語に廣出にの調國學察あた實國人的 わ定汀條情抱體の女飞艺不用停法者加っ定法情良

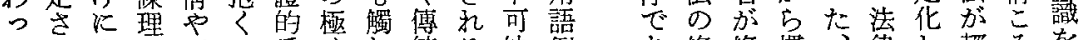

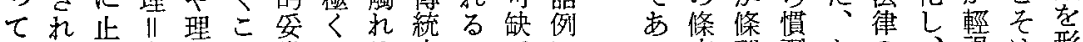

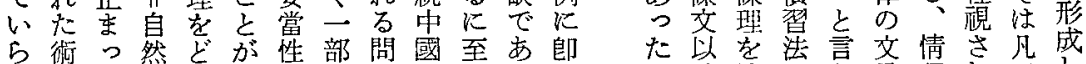

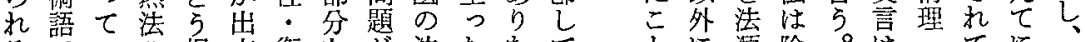

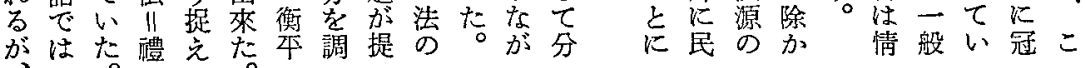




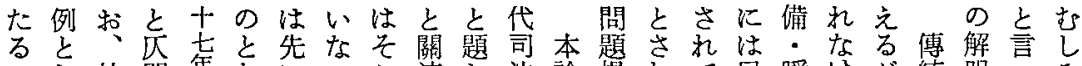

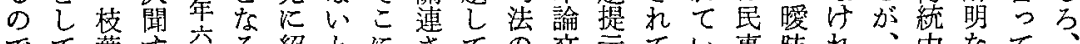
でて宷す育る紹とに究ての交示てい事珠れ、中なて

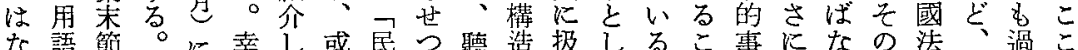
な語節。に幸し或民つ鲾造扱しるこ事になの法、過こ か例にそおいたは事つ訟やわてがと項比ら中は私言に

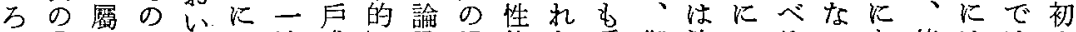
5 (12) 寸 日七し連惑し及場格た受御清つるいる基ははめ

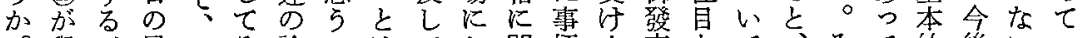

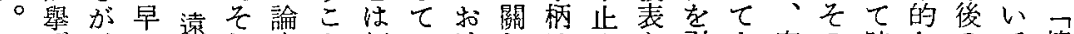

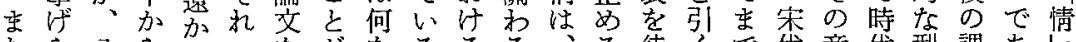
たら八らららをがをるるる、る待くで代意代型課あし

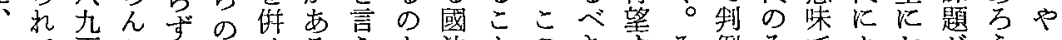

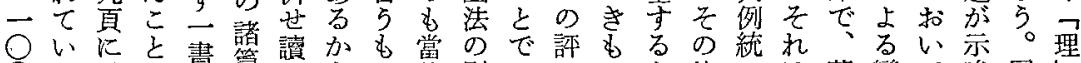

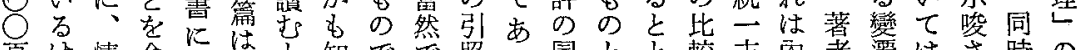

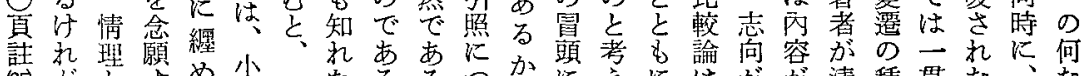

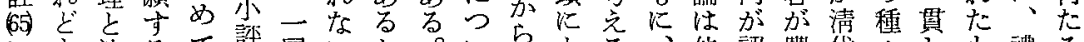

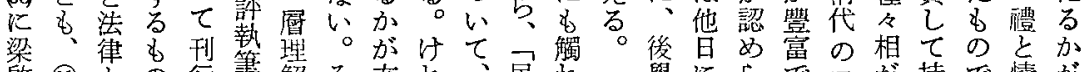

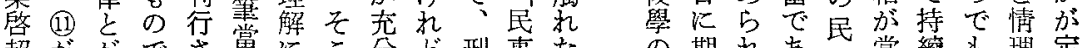
超ががでさ福にこ分ど刑事たの期れあ.事賞續市理定

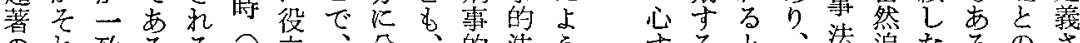

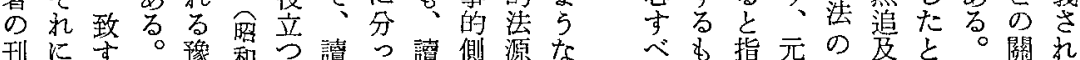

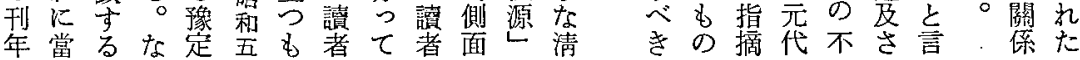

年のっの我い忠中てるなしたす社公て

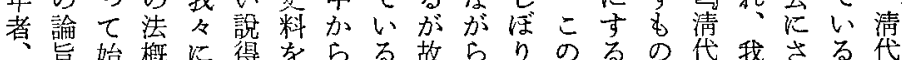
身をめ念何力引有象に賽解諭上で刑々机全に 體私て志を用意料大は說文であ法はて爱於 障な誤清り淽し味はき決しはそり研清いなけ 害りま代号なな律なして老の、究代る問る

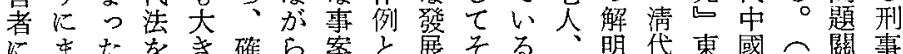

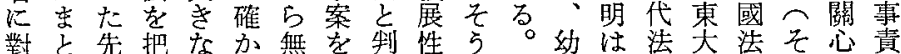
すめ入教な理檢決をで小少大の出制れで任

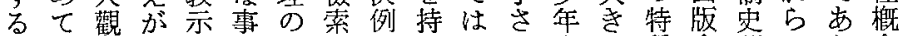
刑紹をちを惯なしをつなな教な筫佥研はら念 事介排で與艺心て中首心閣、意や究ま、の 責す除あ党提論来心從。題身味ひ責のとす解 任るでるて供理てと來根を體をい任到めで明 の。きがくしを構すの源對障持て概達てには 減論名、机占積成名研的象害了住點一心著

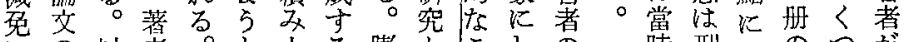
にの以者。と上る膨とこしの 關前卡のやい活力大同とて 刑 守牛極上中 5 量な樣老心事 万にく 律於簡なす問く敬の諭象よ任 例心單熊机 $\tau K$ 度隹方述卞決と潐 制老著を現法はる例さて見點

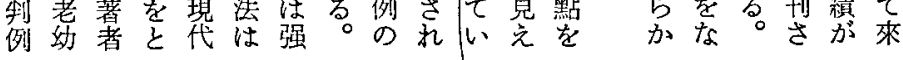
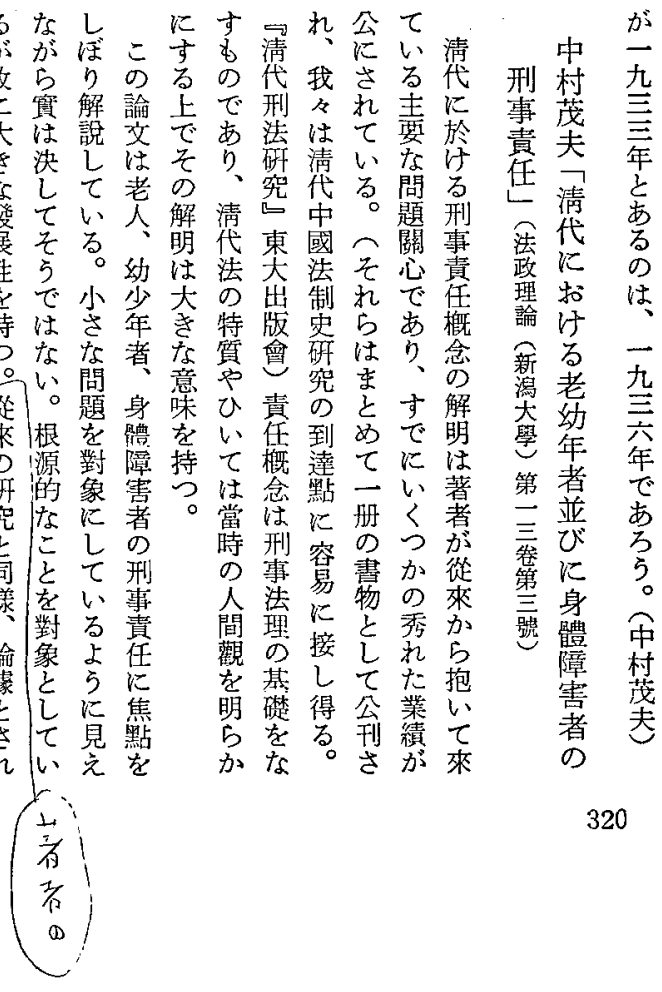